University of Nebraska - Lincoln

DigitalCommons@University of Nebraska - Lincoln

1985

\title{
Predation in Insular Plant Dynamics: An Experimental Assessment of Postdispersal Fruit and Seed Survival, Enewetak Atoll, Marshall Islands
}

Svata M. Louda

University of Nebraska - Lincoln, slouda1@unl.edu

Paul H. Zedler

San Diego State University

Follow this and additional works at: https://digitalcommons.unl.edu/bioscilouda

Part of the Ecology and Evolutionary Biology Commons

Louda, Svata M. and Zedler, Paul H., "Predation in Insular Plant Dynamics: An Experimental Assessment of Postdispersal Fruit and Seed Survival, Enewetak Atoll, Marshall Islands" (1985). Svata M. Louda Publications. 1.

https://digitalcommons.unl.edu/bioscilouda/1

This Article is brought to you for free and open access by the Papers in the Biological Sciences at DigitalCommons@University of Nebraska - Lincoln. It has been accepted for inclusion in Svata M. Louda Publications by an authorized administrator of DigitalCommons@University of Nebraska - Lincoln. 


\title{
PREDATION IN INSULAR PLANT DYNAMICS: AN EXPERIMENTAL ASSESSMENT OF POSTDISPERSAL FRUIT AND SEED SURVIVAL, ENEWETAK ATOLL, MARSHALL ISLANDS ${ }^{1}$
}

\author{
SvaŤA M. Louda and Paul H. Zedler \\ School of Biological Sciences, University of Nebraska, Lincoln, Nebraska 68588, and \\ Biology Department, San Diego State University, San Diego, California 92182
}

\begin{abstract}
A B S T R A C T
We studied predation upon the fruits of four common terrestrial plant species of atolls by excluding: 1) all predators; 2) large predators only; and 3) no predators. Each of these treatments was located within the vegetation at three distances from the shore: beach edge of fringing thicket; middle of the thicket; and inner forest. The plants were Terminalia catappa, Messerschmidia argentea, Scaevola taccada, and Guettarda speciosa. Predation loss over the year was significant $(P<0.01)$ for all four species. Location contributed significantly only for $S$. taccada. Amount of loss and predominant type of seed predator for a plant species were related to size and conspicuousness. The largest fruits, those of the widespread tree T. catappa, were destroyed completely at all sites; the damage was done by both insects and terrestrial crabs. The large fruits of $G$. speciosa were destroyed by insects inland and by crabs at the beach edge. The small fruits of $M$. argentea, a plant which is common along the beach, tended to have greater losses away from the beach edge; those losses were caused primarily by insects. For $S$. taccada, which occurred at the beach edge, fruit survival was highest in the middle of the fringe thicket; average damage and disappearance were high and caused primarily by large predators. In sum, the experiment demonstrated that predation by widespread, omnivorous large animals and insects on an atoll island was important in survival of fruits and enclosed seeds. We conclude that this interaction could have a significant influence on the dynamics of plants on atolls.
\end{abstract}

SEED PREDATION BY ANIMALS is common (e.g., Janzen, 1971; Bohart and Koerber, 1972; Hubbell, 1980), and mortality of tree seeds is often especially severe following dispersal from the parent (e.g., Watt, 1923; Janzen, 1971, 1983; Pinowski and Kendeigh, 1977; Howe and Smallwood, 1982). Such losses are often significant for plant demography (Harper 1969, 1977). For example, destruction of seeds and fruits can limit plant recruitment (Louda 1982a, b, 1983) or determine plant distribution (Janzen, 1975; Louda, 1982b).

Atoll plants depend on propagules for recolonizations and persistence (Carlquist, 1974). Thus, predation on invading propagules, both by cosmopolitan species such as terrestrial hermit crabs (Weins, 1962) and by insects (Janzen, 1971), could be important for our understand-

${ }^{1}$ Received for publication 21 April 1984; revision accepted 9 October 1984.

Janet and Phil Lamberson placed and maintained our equipment. Ted Turk retrieved the units for us. Tom Ebert and Adrian Wenner provided encouragement and advice at Enewetak. Diane Baxter, Mark Hay, Kathleen Keeler, Ken McKaye, Mike Salmon, Don Strong and Jasper Trendall discussed and improved the original manuscript. The United States D.O.E. (E.R.D.A.) and the Mid-Pacific Marine Laboratory provided funding. ing of insular plant dynamics and biogeography (MacArthur, 1972). However, quantitative and experimental data on the fate of plant propagules on oceanic islands, and on the role of predators in that fate, do not exist (Weins, 1962; Carlquist, 1965, 1970, 1974; Howe and Smallwood, 1982).

Although herbivory and seed predation have been hypothesized to be low on islands (Janzen, 1971, 1975; Carlquist, 1974), four observations suggested the opposite might be the case on Enewetak Atoll. First, evidence of damage by predators was abundant. We examined fruits collected from trees and from randomly placed quadrats under midcanopy of several common tree species. On the tree, the proportion damaged by predispersal insect predators varied from 0.0 on Scaevola taccada to 0.84 on Cordia subcordata $(N=50 /$ species, pers. observ.). On the ground the proportion with serious external damage varied from 0.04 on $C$. subcordata to 0.66 on Guettarda speciosa; similar levels of damage were found on several islands of the atoll (pers. observ.).

Second, terrestrial hermit crabs were common and especially dense near the beach edge of the vegetation (pers. observ.; Page and Willason, 1982). These animals have been ob- 
served damaging plants (Rock, 1902, in Fosberg, 1956; Degener and Gillaspy, 1955; Niering, 1956; Palumbo and Gessel, in Welander et al., 1966). Weins (1962: p. 436) hypothesized that they were responsible for the depauperate flora of Canton Atoll.

Third, we watched hermit crabs (Coenobita spp.) handle and tear on fruits and we determined that they can damage them and the enclosed seeds. We confined ten of the most common species, $C$. perlatus, to cages (30-cm radius, 20-cm high Vexar mesh) for 48 and $72 \mathrm{hr}(3$ replicates). Each cage contained ten fruits: Guettarda speciosa (2 mature, 2 green), Scaevola taccada (2 mature, 2 green), and Terminalia catappa ( 2 mature). The crabs fed on all three species, damaging all of the mature fruits within $48 \mathrm{hr}$. Unexpectedly, all green fruits offered were avoided by the crabs. More severe damage was evident after $72 \mathrm{hr}$.

Fourth, evidence of insect feeding was also common; we found mined seeds, frass (Fig. $1 \mathrm{~A}, \mathrm{C})$ and lepidopteran larvae (Gelechiidae) in fruits.

Thus, our purpose was to evaluate experimentally the contribution of both insect and $\mathrm{crab}$ predators to the survival of fruits and seeds of the common tree species of Enewetak. Specifically we asked: 1) Does predation decrease fruit or seed survivorship significantly over a year? 2) Is loss related to fruit traits? 3) Does predation intensity diminish inland? 4) Do different predators affect fruit or seed survivorship differentially?

MATERIALS AND METHODS-Study area and species-We worked on Ananij Island in the southern portion of Enewetak Atoll $\left(11^{\circ} 21^{\prime} \mathrm{N}\right.$, $162^{\circ} 21^{\prime} \mathrm{E}$, see map in Page and Willason, 1982).

The available seed predators on Pacific atolls include insects (Darlington, 1943, 1965; Zimmerman, 1948; Usinger and La Rivers, 1953; Gressitt, 1954, 1963, 1964) and terrestrial hermit and coconut crabs (Weins, 1962; Grubb, 1971; Bryan, 1972; Ball and Haig, 1974). Rodents were confined to larger, inhabited islands of the atoll; none occupy Ananij. Although sea birds may sometimes eat seeds, they are generally carnivorous and were rare inside the vegetation of Ananij.

The vegetation of Ananij was typical for the intermediate-size islands of dry atolls in the Marshall Islands (Taylor, 1950; Hatheway 1953; Niering, 1956, 1963; St. John, 1960; Palumbo, 1962; Woodbury, 1962; Weins, 1962; Welander et al., 1966). The central portion of the island was forest, mainly of Pisonia grandis ("kangl") (St. John, 1960; Koranda et al., 1973), with scattered coconut palms (Cocos nucifera).
This forest had a dense canopy and little undergrowth. In contrast, the fringe vegetation, surrounding the central forest, was dense thicket. The beach edge of that fringe was composed primarily of Scaevola taccada (Goodeniaceae) and Messerschmidia argentea (Boraginaceae). The systematics of the Pacific Scaevola are confused; we follow Weins (1962) and Carlquist (1974) in calling the Enewetak species $S$. taccada. The inner fringe included saplings and small trees, particularly of $M$. argentea, with Guettarda speciosa (Rubiaceae), Cordia subcordata (Ehretiaceae), Terminalia catappa (Combretaceae), Suriana maritima (Simarubaceae), and some Pisonia grandis (Nyctaginaceae). Ipomoea tuba (Convolvulaceae) vines were common in the crowns. Herbaceous vegetation in open patches and outside the fringe vegetation on Ananij Island includes: Ipomoea pes-capre (Convolvulaceae), Lepturus repens (Poaceae), and Fimbristylis atollensis (Cyperaceae).

Our experimental fruits were from the species that were in fruit in early October (Fig. 1): $M$. argentea has round, peppercorn-like fruits (2$3 \mathrm{~mm}$ diam, 2 seeds/fruit); $S$. taccada has white, round fruits ( 2 seeds/drupe) with a fleshy exocarp and hard endocarp (8-9 $\mathrm{mm}$ diam); $T$. catappa has almond-shaped fruits (2 seeds/ drupe) with a hard, corky husk (15-20 mm long); and, G. speciosa has round fruits (2448 seeds/fruit) with tough, fibrous mesophyll (15-20 mm diam). Scaevola taccada and $M$. argentea occur predominantly along the beach while both $T$. catappa and $G$. speciosa occur primarily in the midst of the fringe vegetation (St. Johns, 1960; Weins, 1962; Koranda et al., 1973). Fruits of Pisonia grandis, the dominant tree in the center of the larger islands (St. John. 1960; Koranda et al., 1973), are small (5-6 $\mathrm{mm}$ long) and spindle-shaped but were not available in October.

Exclusion experiment design-To evaluate postdispersal predation pressure, we used three treatments, putting fruits into three types of containers: 1) small-mesh bags that excluded all animals; 2) large-mesh bags that excluded large animals, such as crabs, but not small ones: such as moths or beetles; and 3) for a control. large-mesh, open wire trays that confined the fruits but allowed access by all predators. The small-mesh bags were made of $1-\mathrm{mm}^{2}$-mesh fiberglass screening and excluded all predators except those inside fruits before the experiment. The large-mesh bag was made of 25 . $\mathrm{mm}^{2}$-mesh $\operatorname{Vexar}^{\mathrm{R}}$ plastic. Each bag $(10 \times$ $10 \times 1 \mathrm{~cm})$ was sewn shut after seeds wer $\epsilon$ enclosed. The open control basket $(10 \times 10 \times$ 


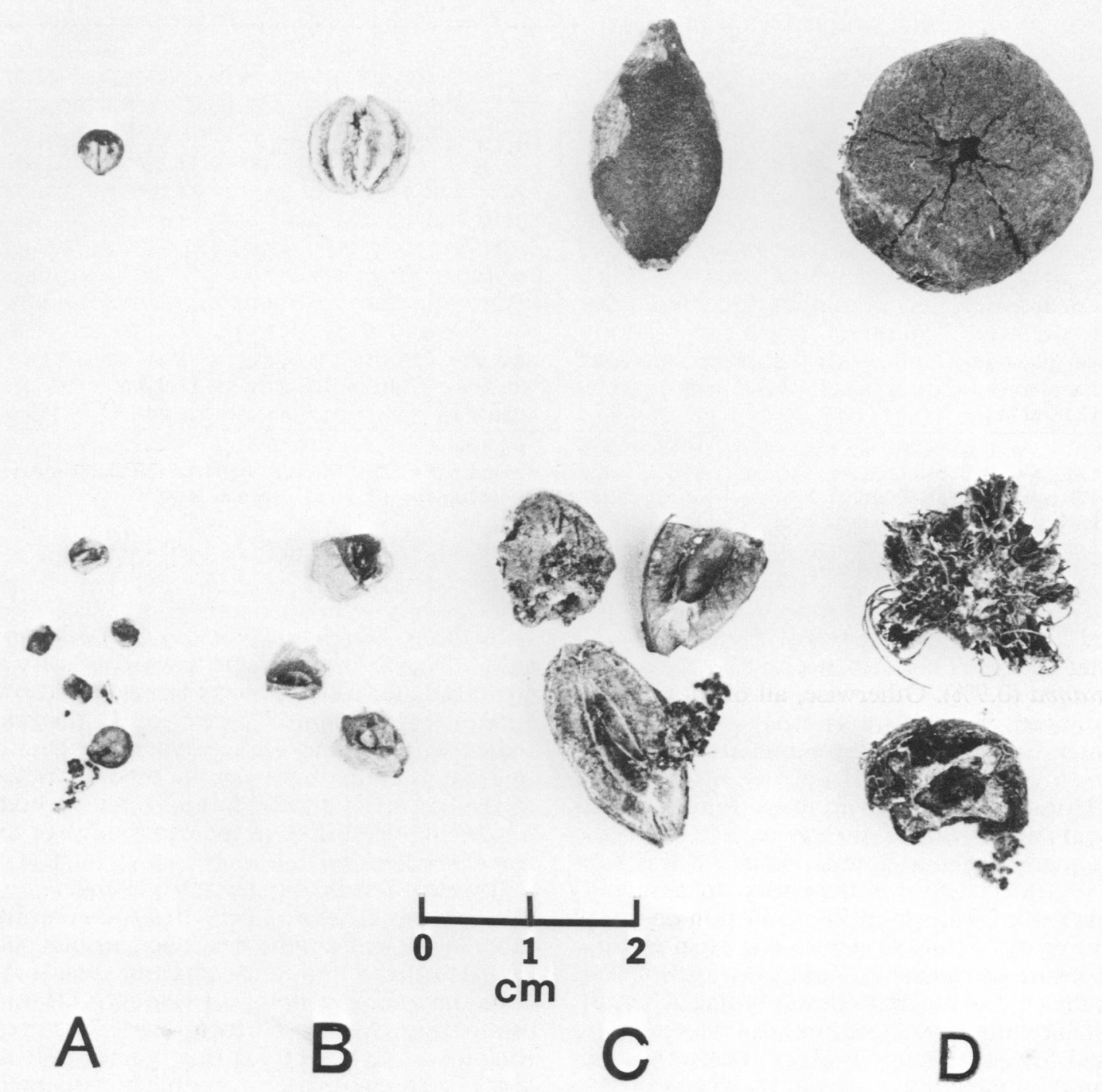

Fig. 1. Propagules of the tree species used in experimental exclusion of predators: $\mathbf{A}=$ Messerschmidia argentea, $\mathrm{B}=$ Scaevola taccada, $\mathrm{C}=$ Terminalia catappa, and $\mathrm{D}=$ Guettarda speciosa. Upper row contains intact fruits. Lower row contains damaged fruits: the top ones have damage caused by the terrestrial hermit crabs and the rest in $A, C, D$ have damage caused by insects, with frass (fecal pellet material).

$2 \mathrm{~cm}$ high) was made of $36-\mathrm{mm}^{2}$-mesh hardware cloth; since the basket was small and settled into the substrate $(1 \mathrm{~cm})$, it is unlikely that it attracted predators. Also, predation levels observed on control fruits were comparable to ambient levels observed.

Each unit contained five fruits each of the four plant species tested, obtained from adult plants. This density $\left(2,000 / \mathrm{m}^{2}\right)$ was about equal to the density observed $\left(2,800 / \mathrm{m}^{2}\right)$ beneath trees (pers. observ.). Three replicates of each type of container were placed $5 \mathrm{~m}$ apart at three distances from the beach edge of the vegetation: at the edge $(0.5 \mathrm{~m}$ into the vegetation), middle of the fringe $(20 \mathrm{~m})$, and in the Pisonia grandis forest $(60 \mathrm{~m})$ on 9 October, 1976. The experiment was terminated 23 September, 1977. Damaged G. speciosa fruits occasionally 
TABLE 1. Number of propagules persisting over the year within three levels of protection from predators at three locations on Ananij Island, Enewetak Atoll

\begin{tabular}{|c|c|c|c|c|c|c|c|c|}
\hline \multirow[b]{3}{*}{ Locations } & \multicolumn{8}{|c|}{ Species ${ }^{\mathrm{b}, \mathrm{c}}$} \\
\hline & \multicolumn{2}{|c|}{$\begin{array}{c}\text { Messerschmidia } \\
\text { argentea }\end{array}$} & \multicolumn{2}{|c|}{$\begin{array}{l}\text { Scaevola } \\
\text { taccada }\end{array}$} & \multicolumn{2}{|c|}{$\begin{array}{c}\text { Terminalia } \\
\text { catappa }\end{array}$} & \multicolumn{2}{|c|}{$\begin{array}{l}\text { Guettarda } \\
\text { speciosa }\end{array}$} \\
\hline & $\bar{x}$ & SE & $\bar{x}$ & $\mathrm{SE}$ & $\overline{\bar{x}}$ & $\mathrm{SE}$ & $\bar{x}$ & $\mathrm{SE}$ \\
\hline \multicolumn{9}{|c|}{ BEACH EDGE OF FRINGE } \\
\hline Small-mesh bag & 5.0 & 0.00 & 5.0 & 0.00 & 5.0 & 0.00 & 5.0 & 0.00 \\
\hline Large-mesh bag & 4.0 & 1.00 & 5.0 & 0.00 & 5.0 & 0.00 & 5.0 & 0.00 \\
\hline Control basket & 3.3 & 0.88 & 2.3 & 1.45 & 3.3 & 0.33 & 2.0 & 0.47 \\
\hline \multicolumn{9}{|c|}{ MIDDLE OF FRINGE SCRUB } \\
\hline Small-mesh bag & 5.0 & 0.00 & 5.0 & 0.00 & 5.0 & 0.00 & 5.0 & 0.00 \\
\hline Large-mesh bag & 2.3 & 0.33 & 5.0 & 0.00 & 5.0 & 0.00 & 5.0 & 0.00 \\
\hline Control basket & 2.3 & 0.33 & 4.7 & 0.33 & 3.7 & 0.67 & 3.7 & 0.67 \\
\hline \multicolumn{9}{|c|}{ CENTRAL PISONIA FOREST } \\
\hline Small-mesh bag & 5.0 & 0.00 & 5.0 & 0.00 & 5.0 & 0.00 & 5.0 & 0.00 \\
\hline Large-mesh bag & 3.3 & 0.67 & 5.0 & 0.00 & 5.0 & 0.00 & 5.0 & 0.00 \\
\hline Control basket & 3.0 & 1.00 & 0.7 & 0.33 & 1.7 & 0.88 & 3.0 & 0.00 \\
\hline
\end{tabular}

${ }^{a} N=5$ propagules/species/treatment, 3 replicates/treatment/location.

b $F_{\max }$ test for homoscedasticity among treatment within species $(\min F=1.00): F_{\max 0.05[9,2]}>0.05$ for all four species.

c Two-way ANOVA, Model I, results for each species; significant results are summarized as follows:

Exclusion treatment: $P \leq 0.01$ for all four species.

Location: $P<0.05$ for $S$. taccada; $P<0.10$ for $G$. speciosa; and N.S. for $M$. argentea and T. catappa.

Interaction: $P<0.01$ for $S$. taccada; $P<0.10$ for $T$. catappa and $G$. speciosa; and N.S. for $M$. argentea.

had a few viable, undamaged seeds $(8.4 \%$ of total seeds). This also occurred once for $T$. catappa $(0.9 \%)$. Otherwise, all of the seeds in damaged fruits were completely destroyed. Thus, no viable seeds remained in the vast majority of damaged fruits.

Homogeneity of variances among treatments was evaluated for each species using the $F_{\max }$ test. For most comparisons two-way ANOVA (Model I) was then used to assess: 1) survival of fruits, and 2) proportion damaged among those surviving in relation to predation exposure and location (Rohlf and Sokal, 1981). In the case of heteroscedasticity, the KruskallWallace nonparametric one-way ANOVA was used for each factor. Probabilities were compared by the conservative test of non-overlap of $95 \%$ confidence intervals (Browne, 1979).

Disappearance from the controls was considered animal-mediated mortality since the fruits were consumable by animals present and since the baskets remained stable and presented a barrier to chance movement. Disappearance rates from the control units may have overestimated dispersal mortality for only one species, Scaevola taccada. The fruit traits for this species, including color, fleshy exocarp and exceptionally hard seed coat, made it conspicuous among the fruits tested, suggesting that bird transport may have caused some dispersal. Otherwise, disappearance rates should accurately quantify differential survival in relation to location, both within and between species.
RESULTS-Predation pressure in open controls-Disappearance from control baskets was significant for all 4 species (Table 1) and was greatest in the central forest for $S$. taccada. None of the species had trends in persistence over the year that fit our initial prediction that fruits and seeds should have higher survival inside the forest than at the beach edge of the fringe vegetation.

Ambient levels of damage were high (Table 2). Since experimental densities were comparable to observed densities, these results suggest that direct mortality was important. All T. catappa fruits remaining in the controls were totally destroyed at all locations. Thus, predation was so severe for this species that no spatial gradient in intensity could be discerned. Highest damage to each of the other three species appeared to occur: at the beach edge for $G$. speciosa, in the fringe for $M$. argentea, and in the forest for S. taccada (Table 2).

The annual probability of survival and recruitment with predation (Fig. 2) was estimated as the product of: 1) fruit persistence (Table 1), and 2) the proportion undamaged among fruits and seeds persisting in open baskets (Table 2). The recruitment probability of $T$. catappa was extremely low $(0.0, \mathrm{SE} 0.00)$ at all locations (Fig. 2). Recruitment probability by $G$. speciosa was also low on the average $(0.21$, SE $0.05, N=9)$, but tended to increase away from the beach edge $(0.09,0.26$, 0.35 , respectively). Average chance of recruitment for $S$. taccada was also low $(0.17, \mathrm{SE}$ 
TABLE 2. Propagules damaged (\%) among those remaining within three levels of protection from predators at three locations on Ananij Island ${ }^{\mathrm{a}, \mathrm{b}}$

\begin{tabular}{|c|c|c|c|c|c|c|c|c|}
\hline \multirow[b]{3}{*}{ Locations } & \multicolumn{8}{|c|}{ Species $^{\mathrm{b}, \mathrm{c}}$} \\
\hline & \multicolumn{2}{|c|}{$\begin{array}{l}\text { Messerschmidia } \\
\text { argentea }\end{array}$} & \multicolumn{2}{|c|}{$\begin{array}{l}\text { Scaevola } \\
\text { taccada }\end{array}$} & \multicolumn{2}{|c|}{$\begin{array}{c}\text { Terminalia } \\
\text { catappa }\end{array}$} & \multicolumn{2}{|c|}{$\begin{array}{l}\text { Guettarda } \\
\text { speciosa }\end{array}$} \\
\hline & $\bar{x}$ & $\mathrm{SE}$ & $\bar{x}$ & $\mathrm{SE}$ & $\bar{x}$ & $\mathrm{SE}$ & $\bar{x}$ & SE \\
\hline \multicolumn{9}{|c|}{ BEACH EDGE OF FRINGE } \\
\hline Small-mesh bag & 9.3 & 8.86 & 0.0 & 0.00 & 9.3 & 8.86 & 2.4 & 8.86 \\
\hline Large-mesh bag & 29.2 & 6.14 & 0.0 & 0.00 & 19.4 & 13.08 & 9.3 & 8.86 \\
\hline Control basket & 16.4 & 13.01 & 55.0 & 2.89 & 100.0 & 0.00 & 79.7 & 13.37 \\
\hline \multicolumn{9}{|c|}{ MIDDLE OF FRINGE SCRUB } \\
\hline Small-mesh bag & 9.3 & 8.86 & 0.0 & 0.00 & 14.0 & 11.56 & 14.0 & 11.56 \\
\hline Large-mesh bag & 11.7 & 11.69 & 0.0 & 0.00 & 67.7 & 8.07 & 46.6 & 3.85 \\
\hline Control basket & 44.4 & 3.25 & 50.4 & 7.43 & 100.0 & 0.00 & 64.5 & 1.32 \\
\hline \multicolumn{9}{|c|}{ CENTRAL PISONIA FOREST } \\
\hline Small-mesh bag & 2.4 & 7.00 & 0.0 & 0.00 & 14.0 & 11.56 & 8.5 & 16.92 \\
\hline Large-mesh bag & 50.0 & 8.66 & 0.0 & 0.00 & 20.0 & 0.00 & 32.3 & 8.07 \\
\hline Control basket & 6.7 & 15.00 & 100.0 & 0.00 & 100.0 & 0.00 & 44.3 & 6.50 \\
\hline
\end{tabular}

a Statistics on arcsine-transformed proportions; $N=5$ propagules/species/treatment, with 3 replicates/treatment/ location.

${ }^{\mathrm{b}} F_{\max }$ test for homoscedasticity among treatments within species (min. $F=1.00$ ): $F_{\max 0.05[9,2]}>0.05$ for all species except Terminalia catappa; Kruskall-Wallis test on $T$. catappa for each factor separately: location $\mathrm{H}=3.21$ (N.S.) and treatment $\mathrm{H}=5.51(0.10>P>0.05)$.

c Two-way ANOVA, Model I, results for each species, except $T$. catappa; significant results are summarized as follows:

Exclusion treatment: $P \leq 0.01$ for all species except $M$. argentea (N.S.).

Location: $P<0.001$ for $S$. taccada and N.S. for the other two species.

Interaction: $P<0.001$ for $S$. taccada and N.S. for the other two species.

$0.04, N=7)$ and decreased significantly in the forest $(0.30,0.32,0.00$, respectively). Probability of recruitment of $M$. argentea was generally high $(0.50$, SE $0.05, N=9)$ and appeared lower in the fringe and higher at either end of the gradient $(0.70,0.26,0.62$, respectively, Fig. 2).

Predator exclusion-Fruit persistence increased (Table 1) and damage decreased significantly (Table 2) when predators were excluded. No fruits disappeared from the smallmesh cages (Table 1). Very few fruits $(4.5 \%)$ were lost from the large-mesh cages (only $M$. argentea: Table 1).

Predator destruction was highly significant (ANOVA) for $S$. taccada, $T$. catappa and $G$. speciosa (Table 2). Predation intensity ranked highest to lowest: T. catappa, G. speciosa, $M$. argentea, and $S$. taccada. This ranking occurred consistently: 1) for predispersal predation $(12.3,7.5,6.5$ and $0.0 \%$, respectively); 2) for all insect damage combined $(34.6,27.8$, 24.7 , and $0.0 \%$, respectively); and 3 ) for the increment added by postdispersal insect damage $(22.3,20.3,18.2$ and $0.0 \%$, respectively).

Insect predation destruction (large- plus small-mesh treatments) was relatively high (12$82 \%$ ) on all species except $S$. taccada, whose fruits were not consumed by an insect predators. Consumption by larger predators, pri- marily hermit crabs, was very high on three of the four species (Table 2): T. catappa (100\%), S. taccada (79\%) and G. speciosa (63\%). Scaevola taccada was removed both at the beach $(55 \%)$ and in the fringe (50\%) but the highest rates of removal $(100 \%)$ were observed in the forest. Consequently, location significantly affected $S$. taccada fruit survival (Table 2). Destruction by crabs, however, was always highest for the large fruits of T. catappa (100\%) and $G$. speciosa (44.3-79.7\%).

The probability of a fruit and its seeds surviving the predation pressure was species-specific (Fig. 2). Predator exclusion demonstrated that the overall chance of surviving the year without damage (with $95 \%$ C.L.) was significantly lower for T. catappa (0.0, C.L. 0.00$0.13)$ than for $M$. argentea $(0.4$, C.L. 0.270.62) (nonoverlap of 95\% C.L.: Browne 1979). The probabilities were intermediate for both S. taccada (0.2, C.L. 0.08-0.35) and G. speciosa (0.2, C.L. 0.11-0.43). Also, the contribution of location to rate of loss differed for the species studied. For $M$. argentea, combined losses caused higher recruitment potential at the beach and in the forest $(0.56-0.57)$ than in the thicket $(0.26$, nonoverlap of $95 \%$ C.L., Fig. 2 ). For $S$. taccada, the probability of recruitment was zero in the forest. For G. speciosa, the probability of recruitment suggested an increasing trend from the beach into the Pisonia 
A: $\underline{\text { M. argentea }} \quad$ B: $\underline{\text { S. taccada }}$
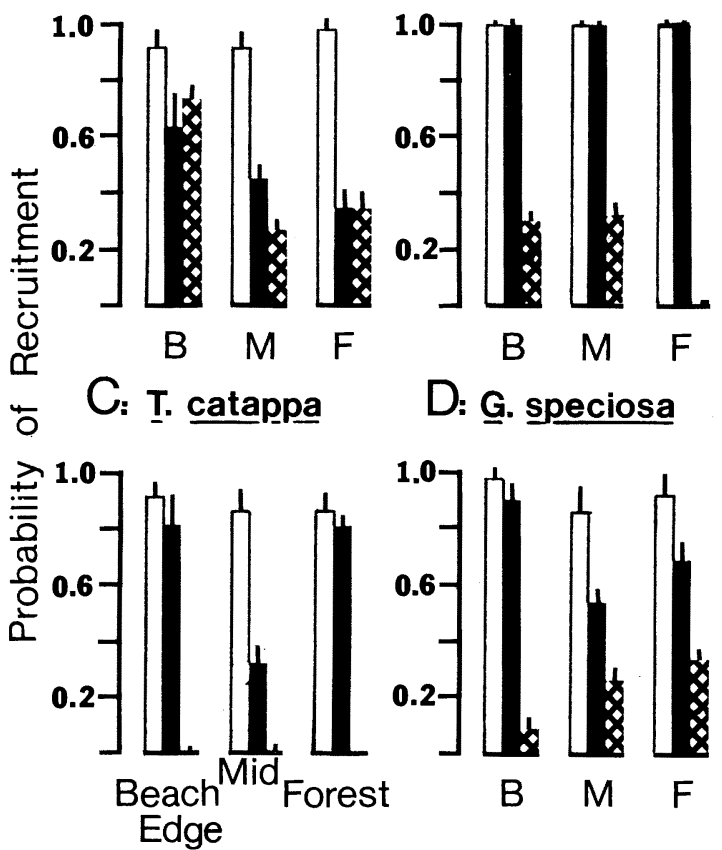

Fig. 2. Probability of fruit survival and seed recruitment over one year at different levels of predation intensity along the gradient from beach edge of the fringe scrub into the central Pisonia forest on Ananij Island: $\square=$ after predispersal seed predation (small-mesh bags); $\mathbf{\square}=$ after insect postdispersal seed predation only (large-mesh bags); and $=$ after both insect and terrestrial crab seed predation (controls), with $\mathrm{A}=$ Messerschmidia argentea, $\mathrm{B}=$ Scaevola taccada, $\mathrm{C}=$ Terminalia catappa, and D $=$ Guettarda speciosa.

forest (Fig. 2). Finally, for T. catappa, damage by crabs was so severe that the probability of undamaged fruits with viable seeds occurring was essentially zero in all locations (Fig. 2).

Discussion-Predation in species dynam$i c s-$ Predation was significant in the survival of fruits and their seeds over the year for all of the species. The amount of damage differed among the species (Tables 1, 2). Location was important in the predation observed on $S$. taccada, and possibly on $G$. speciosa (Table 1). The simple, generalized gradient in total predation pressure, which we expected after observing the high densities of Coenobita spp. at the beach edge of the vegetation, did not occur. Absolute levels of loss appeared related to the characteristics of the propagules.

The Indian almond (Terminalia catappa) had a large fruit (Fig. 1) with a single large seed. It also bore the greatest damage and loss. Predation, particularly by terrestrial crabs, reduced the probability of recruitment by $T$. ca- tappa to zero $(P<0.001)$ along our gradient. Establishment must be sporadic. Thus we suggest that predation must contribute to the patchy occurrence of mature $T$. catappa in Enewetak.

The fruits of Guettarda speciosa also suffered severe damage. It had the largest fruits, but with multiple (16-24) small seeds in them (Fig. 1). Adult plants of this species were patchy in their occurrence. The spatial trend in potential recruitment was inversely related to terrestrial hermit crab abundance (fig. 2, Page and Willason, 1982); so, colonization by G. speciosa may be limited by crab predator effectiveness. Further work is warranted.

Scaevola taccada has intermediate-sized, but conspicuous, fruits which had the highest rate of disappearance among the species, particularly in the central forest. The white, pulpy exterior of the fruit (Fig. 1) may have attracted birds. For this species, disappearance rates probably overestimated absolute mortality and included propagule redistribution as well as mortality. However, high levels of crab damage occurred, suggesting that there was also an important mortality component to disappearance (Table 2).

Messerschmidia argentea had the smallest fruits (Fig. 1) and the most extensive postdispersal insect predation at the beach edge and in the central forest. Both the location and the magnitude of insect damage were unexpected. The other two species with high levels of insect damage to fruits and seeds, T. catappa and $G$. speciosa, had much larger fruits (Fig. 1) and both had higher rates of insect predation on those fruits in the fringe vegetation (Table 2).

Catastrophic events and disturbance are known to be important in the dynamics of island plants (Weins, 1962; Carlquist, 1974; Zedler and Louda, in prep.). However, the patterns and the intensity of destruction that we observed suggest that predation could also contribute to the patterns of plant abundance and observed distribution for these species. Predation severely reduced the number of propagules available to colonize after disturbance. Three points are clear: 1) insect predators reduced the potential for recruitment of two species (M. argentea, $T$. catappa); 2) terrestrial crabs and perhaps birds contributed significantly to the absence of $S$. taccada in the forest (Table 1, Fig. 2); and 3) terrestrial crabs severely restricted fruit and seed survival, and did so throughout the gradient for $T$. catappa (Fig. 2).

Predation and insular dynamics - The magnitude of loss demonstrated has implications 
for insular community structure. The results clearly show that in spite of the usual simplification in species composition of oceanic island communities (MacArthur and Wilson, 1967; MacArthur, 1972; Levins and Heatwole, 1973; Carlquist, 1974), predation can be intense and highly significant in fruit and seed survival. Our results on an atoll island parallel experimental results assessing herbivory in noninsular systems (Cantlon, 1969; Manley, Butcher and Cantlon, 1975; Waloff and Richards, 1977; Louda, 1982a, b, 1983, 1984). They further substantiate Simberloff's $(1970,1974)$ criticism of imputing causation and mechanism in island community dynamics solely from observational data.

Predation has typically been assumed to be insignificant in the colonization, persistence, and species composition upon islands. Most work on island biogeography and community dynamics (see Hamilton et al., 1963; MacArthur and Wilson, 1967; Simberloff and Wilson, 1969, 1970; Diamond, 1970, 1975; MacArthur, 1972; Simberloff (1974) has focused on: 1) species characteristics which promote or retard dispersal; 2) island characteristics, such as size, topography and isolation; and, 3) competition among species that arrive on an island. MacArthur (1972: p. 93), however, pointed out there were at least three potentially important processes in island population numbers: random fluctuation, competition, and predation. Predation obviously needs further consideration.

There are several reasons that differential loss among fruits and seeds has not been recognized as contributing to the composition of island associations. MacArthur (1972: p. 96), for example, observed: "Species on islands are often astonishingly abundant, being free from predators and often from competitors." Janzen (1971) predicted that the establishment and persistence of seed predators on islands should be rare. And, he found an insular reduction in insect diversity (Janzen, 1973) and insular absence of specialized bruchid beetles (Janzen, 1975). Observations such as these have contributed to the assumption of low overall predation intensity on islands. Alternately, our results showed that predation intensity, and potentially differential selectivity among seeds, by generalized omnivorous predators, contributed to colonization and persistence probabilities on this small oceanic island. Janzen focused on specialized insect predators; we focused on all predators and on total postdispersal losses.

It is not surprising that predation by hostspecific predators is lower on islands; however, if omnivorous seed predators exist and if density compensation occurs, then overall predation pressure can still be high. Insects can be extremely common on oceanic islands (Usinger and LaRivers, 1953; Hesse, Allee and Schmidt, 1951, Allan et al., 1973). Furthermore, density compensation is a common phenomenon on islands (e.g., see Schoener, 1974). Heatwole and Levin (1972) found rapid recovery of trophic distribution, along with the return of species richness to predefaunation levels (analysis of Simberloff and Wilson's $(1969,1970)$ data from defaunated islands). Consequently, we conclude that species richness, by itself, is not indicative of potential predation pressure on colonizing seeds.

Our results show that generalized predators, when at high densities, influenced fruit and seed survivorship, and thus potential colonization, among co-occurring plants on an atoll island. We suggest incorporation of predation into models and into discussions of insular plant biogeography is warranted.

\section{LITERATURE CITED}

Allan, J. D., L. W. Barnthouse, R. A. Prestbye, And D. R. STRONG. 1973. On foliage arthropod communities of Puerto Rican second growth vegetation. Ecology 54: 628-632.

BALl, E., AND J. HaIG. 1974. Hermit crabs of the Eastern Tropical Pacific. Bull. South. Calif. Acad. Sci. 73: 95104.

Bohart, G. E., AND T. W. Koerber. 1972. Insects and seed production. In T. T. Kozlowski [ed.]. Seed biology, Vol. 3, pp. 1-50. Academic Press, New York.

BRowNE, R. H. 1979. On visual assessment of the significance of a mean difference. Biometrics 35: 657665.

Bryan, E. H., JR. 1972. Life in the Marshall Islands. Pacific Science Information Center. Bernice P. Bishop Museum Press, Honolulu.

CANTLON, J. E. 1969. The stability of natural populations and their sensitivity to technology. Brookhaven Symp. Biol. 22: 197-205.

CARLQUIST, S. 1965. Island life. Natural History Press, New York.

- 1970. Hawaii, a natural history. Natural History Press, New York.

. 1974. Island biology. Columbia University Press, New York.

DARlington, P. J., JR. 1943. Carabidae of mountains and islands: data on the evolution of isolated faunas and on the atrophy of wings. Ecol. Monogr. 13: 3761.

-1965. Biogeography of the southern end of the world. Harvard University Press, Cambridge, Mass.

Degener, O., and E. Gillaspy. 1955. Canton Island, South Pacific. Atoll Res. Bull. 41: 1-51.

DiAmOND, J. M. 1970. Ecological consequences of island colonization by Southwest Pacific birds. II. The effect of species diversity on total population density. Proc. Natl. Acad. Sci. USA 67: 1715-1721.

1975. Assembly of species communities. In $\mathrm{M}$. L. Cody and J. M. Diamond [eds.], Ecology and evo- 
lution of communities, pp. 342-444. Belknap Press of Harvard University Press, Cambridge, Mass.

FosBerg, F. R. 1956. Studies in Pacific Rubiaceae: IIV. Brittonia 8: 165-178.

GRESSITT, J. L. 1954. Insects of Micronesia: introduction. Volume I. Bernice P. Bishop Museum Press, Honolulu.

- (ED.) 1963. Pacific Basin biogeography. Bernice P. Bishop Museum Press, Honolulu.

- 1964. Insects of Campbell Island: summary. Pac. Insects Monogr. 7: 531-600.

GrubB, P. 1971. Ecology of terrestrial decapod crustaceans on Aldabra. Philos. Trans. R. Soc. (B) 260: 411416.

Hamilton, T. H., I. Rubinoff, R. H. Barth, AND G. L. BusH. 1963. Species abundance: natural regulation of insular variation. Science 142: 1575-1577.

HARPER, J. L. 1969. The role of predation in vegetational diversity. Brookhaven Symp. Biol. 22: 48-62.

-1977. The population biology of plants. Academic Press, New York.

HATHEWAY, W. H. 1953. The land vegetation of Arno Atoll, Marshall Islands. Atoll Res. Bull. 16: 1-68.

Heatwole, H., ANd R. Levins. 1972. Biogeography of the Puerto Rican bank: species-turnover on a small cay, Cayo Ahogado. Ecology 54: 1042-1055.

Hesse, R., W. C. Allee, And K. P. Schmidt. 1951. Ecological animal geography, 2nd ed. John Wiley \& Sons, New York.

Howe, H. F., AND J. SMallwood. 1982. Ecology of seed dispersal. Annu. Rev. Ecol. Syst. 13: 202-228.

HubBell, S. P. 1980. Seed predation and coexistence of tree species in tropical forests. Oikos 35: 214-229.

JANZEN, D. H. 1971. Seed predation by animals. Annu. Rev. Ecol. Syst. 2: 465-492.

. 1973. Sweep samples of tropical foliage insects: effects of seasons, vegetation types, elevation, time of day and insularity. Ecology 54: 687-701.

- 1975 . Behavior of Hymenaea courbaril when its predispersal seed predator is absent. Science 189:154147.

- 1983. Dispersal of seeds by vertebrate guts. In D. J. Futuyma and M. Slatkin [eds.], Coevolution, pp. 232-262. Sinauer Associates Inc., Sunderland, Mass.

Koranda, J. J., J. R. Martin, S. E. Thompson, M. L. StUART, AND D. R. MCINTYRE. 1973. Terrestrial biota survey. In Enewetak radiological survey. October 1973. Vol. 1, pp. 225-238. Atomic Energy Commission, NVO-140 Nevada Operations Office, Las Vegas.

Levins, R., AND H. Heatwole. 1973. Biogeography of the Puerto Rican bank: introduction of species into Palominitos Island. Ecology 54: 1056-1064.

LoudA, S. M. 1982a. Limitation of the recruitment of the shrub Haplopappus squarrosus (Asteraceae) by flower- and seed-feeding insects. J. Ecol. 70: 43-53.

- $1982 b$. Distribution ecology: variation in plant recruitment over a gradient in relation to insect seed predation. Ecol. Monogr. 52: 25-41.

- 1983. Seed predation and seedling mortality in the recruitment of a shrub, Haplopappus venetus (Asteraceae), along a climatic gradient. Ecology 64: 511521.

1984. Herbivore effect on stature, fruiting, and leaf dynamics of a native crucifer. Ecology 65: 13791386.
MACARTHUR, R. H. 1972. Geographical ecology. Harper and Row, New York.

- AND E. O. WILSON. 1967. The theory of island biogeography. Princeton University Press, Princeton, N.J.

Manley, G. V., J. W. Butcher, AND J. E. CANTLON. 1975. Relationship of insects to distribution and abundance of Melampyrum lineare (Scrophulariaceae). Pedobiologia 15: 385-404.

NiERING, W. A. 1956. Bioecology of Kapinga-marangi, Caroline Islands: terrestrial aspects. Atoll Res. Bull. 49: $1-32$.

1963. Terrestrial ecology of Kapingamarangi Atoll, Caroline Islands. Ecol. Monogr. 33: 131-160.

Page, H. M., and S. W. Willason. 1982. Distribution patterns of terrestrial hermit crabs at Enewetak Atoll, Marshall Islands. Pac. Sci. 36: 107-117.

Palumbo, R. F. 1962. Recovery of the land plants of Enewetak Atoll following a nuclear detonation. Radiat. Biol. 1: 182-189.

PINOWSKI, J., AND S. C. KendeIGH (EDS.) 1977. Granivorous birds in ecosystems: their evolution, populations, energetics, adaptations, impact and control. Cambridge University Press, New York.

Rohlf, F. J., AND R. R. SoKal. 1981. Statistical tables, 2nd ed. W.H. Freeman and Co., San Francisco.

SCHOENER, T. W. 1974. Resource partitioning in ecological communities. Science 185: 27-39.

SimberlofF, D. S. 1970. Taxonomic diversity of island biotas. Evolution 24: 23-47.

. 1974. Equilibrium theory of island biogeography and ecology. Annu. Rev. Ecol. Syst. 5: 161-182.

— AND E. O. WILSON. 1969. Experimental zoogeography of islands: the colonization of empty islands. Ecology 50: 278-295.

— AND —. 1970. Experimental zoogeography of islands: a two-year record of colonization. Ecology 51: 934-937.

St. John, H. 1960. Flora of Enewetak Atoll. Pac. Sci. 14: 313-336.

TAYLOR, W. R. 1950. Plants of Bikini and other northern Marshall Islands. University of Michigan Press, Ann Arbor.

Usinger, R. L., AND I. LA Rivers. 1953. The insect life of Arno. Atoll Res. Bull. 15: 1-28.

WALOFF, N., AND O. W. Richards. 1977. The effect of insect fauna on growth, mortality and natality of broom, Sarothamnus scoparius. J. Appl. Ecol. 14: 787-798.

WATT, A. S. 1923. On the ecology of British beechwoods, with special reference to their regeneration. I. The causes of failure of natural regeneration of the beech (Fagus silvatica L.). J. Ecol. 11: 1-48.

Weins, H. J. 1962. Atoll environment and ecology. Yale University Press, New Haven, Conn.

Welander, A. D., K. Bonham, L. R. Donaldson, R. F. Palumbo, S. P. Gessel, F. G. Locoman, and W. B. JACKSON. 1966. Bikini-Enewetak Studies, 1964, Part I. Ecological observations, pp. 172-184. University of Washington Laboratory of Radiation Biology, Report UWFL-93, Part I., Seattle, Wash.

WoOdBuRY, A. M. 1962. A review of the ecology of Enewetak Atoll, Pacific Ocean. University of Utah, Institute of Environmental Biological Research, Salt Lake City.

ZiMmERMAN, E. C. 1948. Insects of Hawaii, Vol. 1, Introduction. University of Hawaii Press, Honolulu. 